\title{
PENGARUH PEMBELAJARAN PROBLEM SOLVING MODIFIKASI TERHADAP KEMAMPUAN KOMUNIKASI MATEMATIS SISWA
}

\author{
Dina Nurhasanah ${ }^{1}$, Rizki Wahyu Yunian Putra ${ }^{2}$, Istihana ${ }^{3}$ \\ Universitas Islam Negeri Raden Intan Lampung ${ }^{1,2,3}$ \\ pos-el : nurhasanahdina24@yahoo.com ${ }^{1}$
}

\begin{abstract}
ABSTRAK (TNR, 11, Bold)
Kemampuan komunikasi matematis sangat berperan penting untuk peserta didik dalam mata pelajaran matematika. Meningkatnya kemampuan komunikasi siswa berdampak pada hasil belajar tujuan dari penelitian ini adalah untuk mencari apakah terdapat peningkatan kemampuan komunikasi matematis peserta didik dengan pembelajaran dengan menggunakan metode problem solving modifikasi. Metode yang digunakan ialah metode kuantitatif. Jenis penelitian yang menggunakan Quasy Eksperimen dan desain penelitian menggunakan kelompok kontrol non-ekuivalen dan analisis data yang digunakan dengan one way Anava. Hasil penelitian yang dilakukan adalah $\mathrm{F}_{\text {hitung }}=11,186, \mathrm{~F}_{\text {tabel }}=3,09$ maka $\mathrm{H}_{0}$ ditolak, maka dapat disimpulkan penelitian ini memberikan kesimpulan bahwa terdapat perbedaan terhadap peningkatan kemampuan komunikasi matematis peserta didik.
\end{abstract}

Kata kunci : komunikasi matematis, problem solving modifikasi, pembelajaran aktif

\section{ABSTRACT}

Mathematical communication skills are essential for learners in math learning. Increased numerical ability of students impact on the results of the study aims to determine whether there is improvement in the mathematical communication skills of learners by using methods learning problem solving modification. Method used is quantitative method. The types of research used are Quasy experiments and design experiments used in the design of non-equivalence control groups and data analysis used with one way Anava. The results of the study are $F_{\text {hitung }}=11,186$, $F_{\text {tabel }}=3.09$ then $H_{0}$ rejected, then it can be concluded the research has an influence that is not equal to the mathematical communication skills of learners.

\section{Keywords : communication skills, problem solving modification, active learning}

\section{PENDAHULUAN}

Matematika berperan penting dalam kehidupan, misalnya berbagai informasi dan gagasan banyak dikomunikasikan atau disampaikan dengan bahasa matematis. Matematika diajarkan kepada peserta didik agar peserta didik mendapatkan ilmu pengetahuan untuk diterapkan dalam kehidupan sehari-hari. Di Indonesia kualitas pendidikan matematika sangat memprihatikan (Manullang, 2016;
Purwanto, 2016), peserta didik dalam pembelajaran matematika hanya mengutamakan menghitung dan menghafal rumus (Aprilia 2014), bahkan gurupun hanya berfokus untuk rumus atau pengetahuan yang ada (Anisah, Zulkardi, dan Darmawijoyo, 2013; Rachmayani, 2014). Matematika sangat berperan penting dalam kehidupan (Ikhsan, 2019). Kemampuan matematis siswa yang banyak diungkap diantaranya kemampuan komunikasi 
matematis siswa (Permana dan Sumarmo, 2007).

Kehidupan bangsa salah satu yang mejukan Memajukan dapat dilakukan yaitu dengan meningkatkan perkembangan pendidikan (Ainiyah, 2013). Hal tersebut dipengaruhi perkembangan pendidikan oleh pendidik. Dikarenakan pendidik yang berperanan penting saat proses pembelajaran (Rohman, Yuniarti, dan Permatasari, 2018). Pelajaran metematika memiliki tingkat prestasi yang masih tergolong rendah (Hidayati, Isnani, dan Susongko, 2017; Ratnasari, 2017), hal itu membuat pendidik dapat mewujudkan pembelajaran yang aktif, efektif, kreatif, dan menyenangkan. Matematika merupakan ilmu yang diperlukan untuk kehidupan sehari-hari (Anwar, 2018; Agustiana, Supriadi, dan Komarudin 2019).

Salah satu kegagalan guru dalam pembelajaran matematika saat ini adalah saat mengajukan pertanyaan (Astuti dan Leonard, 2015) atau memberikan soal dikelas yang kurang bervariasi sehingga peserta didik mengalami kesulitan dalam menjawab soal (Rindyana dan Chandra, 2012; Farida, 2015). Pembelajaran dengan menggunakan metode problem solving adalah metode pengajaran dengan cara menyelesaikan suatu masalah yang memberikan penekanan pada penyelesaian suatu masalah secara menalar (Darmawan, 2015; Nadi, Setyowati, dan Saputro, 2016). Pada kenyataannya masih banyak guru yang menggunakan pembelajaran konvensial (Karim, 2011). Pemilihan metode dalam pembelajaran yang kurang tepat juga dapat mempengaruhi peserta didik dalam memahami materi yang akan dijelaskan oleh guru (Emda, 2011).

Adapun tujuan dari pembelajaran menggunakan metode problem solving yaitu: 1) Peserta didik menjadi terampil dalam memilih informasi yang relevan. 2) Menghasilkan keputusan intelektual dari dalam sebagai hadiah interinsik. 3) Meningkatkan potensi intelektual. 4) Melalui proses melakukan penemuan peserta didik belajar bagaimana melakukan penemuan dengan baik. Adapun kelebihan dari pembelajaran problem solving diantaranya :1) Problem solving adalah metode yang tepat untuk memahami isi atau materi dalam suatu pembelajaran. 2) Problem solving dapat menemukan pengetahuan baru lagi peserta didik dalam setiap mata pelajaran. 3) Problem solving dapat membantu peserta didik untuk menyelesaikan suatu masalah pada kehidupan nyata. 4) Problem solving dapat membantu siswa dalam mengembangkan pengetahuannya dan dapat bertanggung jawab dalam pelajaran yang telah didapat serta mengarahkan cara belajar mandiri. 5) Peserta didik lebih aktif dalam aktivitas pembelajaran. 6) memberikan pengalaman belajar sehingga diminati, disukai, serta menjadi pembelajaran yang menyenangkan (Hariawan, Kamaluddin, dan Wahyono, 2014).

Adapun Penelitian yang dilakukan yang dilakukan peneliti sebelumnya dengan pembelajaran yang sama menggunakan pembelajaran problem solving maka penelitian ini bertujuan untuk mengetahui apakah terdapat peningkatan terhadap kemampuan komunikasi matematis dengan pembelajaran yang menggunakan metode problem solving modifikasi. 


\section{METODE PENELITIAN}

Peneliti melakukan penelitian di SMP Negeri 17 Bandar Lampung. Sampel pertama pada kelas VIII 1 dengan pembelajaran menggunakan metode problem solving modifikasi, sampel kedua kelas VIII 9 dengan pembelajaran menggunakan metode problem solving, dan sampel yang ketiga kelas VIII 10 dengan pembelajaran konvensional. Teknik pengambilan sampel yang digunakan penelitian ini adalah dengan menggunakan teknik cluster random sampling. Penelitian ini terdiri dari terdiri dari variabel bebas (X) yaitu pembelajaran dengan menggunakan metode Problem Solving Modifikasi $\left(\mathrm{X}_{1}\right)$, pembelajaran dengan menggunakan metode Problem Solving $\left(\mathrm{X}_{2}\right)$ dan pembelajaran konvensional $\left(\mathrm{X}_{3}\right)$, lalu terdiri dari komunikasi matematis sebagai variabel terikat $(\mathrm{Y})$.

Jenis penelitian ini yaitu Quasy Eksperimen. Pada penelitian ini desain eksperimen yang digunakan adalah desain kelompok non-ekuivalen. Teknik pengumpulan data melalui wawancara, observasi langsung, dokumen dan tes.

Instrumen yang digunakan pada penelitian ini berupa tes uraian (essay) Asumsi untuk uji normalitas yaitu:

Tabel 1. Data Hasil Prestest Kemampuan Komunikasi Matematis

\begin{tabular}{|c|c|c|c|c|c|c|c|}
\hline & & & \multicolumn{6}{|c|}{ Ukuran Tendensi Sentral } & \multicolumn{2}{c|}{$\begin{array}{c}\text { Ukuran variansi } \\
\text { kelompok }\end{array}$} \\
\cline { 4 - 8 } Kelompok & \multirow{2}{*}{$\boldsymbol{X}_{\text {max }}$} & \multirow{2}{*}{$\boldsymbol{X}_{\min }$} & $\overline{\boldsymbol{X}}$ & $\boldsymbol{M}_{\boldsymbol{o}}$ & $\boldsymbol{M}_{\boldsymbol{e}}$ & $\mathbf{J}$ & $\mathbf{S}$ \\
& & & & & & & \\
\hline Eksperimen 1 & 92,86 & 50,00 & 72,66 & 78,57 & 78,57 & 42,86 & 11,24 \\
\hline Eksperimen 2 & 85,71 & 50,00 & 71,21 & 71,43 & 75,00 & 35,71 & 7,94 \\
\hline Konvensional & 82,14 & 50,00 & 66,63 & 71,43 & 71,43 & 32,14 & 10,04 \\
\hline
\end{tabular}

Berdasarkan data hasil pretest kemampuan komunikasi matematis bisa dilihat pada tabel 1. Pada nilai tes saat sebelum pembelajaran berlangsung,
$H_{0}$ : Data Berdistribusi Normal

$H_{1}$ : Data Tidak Berdistribusi Normall

Kriteria Uji : Jika $L_{\text {Hitung }} \leq L_{\text {tabel }}$ Maka $H_{0}$ diterima, sehingga kedua data berdistribusi normal.

Asumsi untuk uji homogenitas yaitu:

$H_{0}$ : Data homogen

$H_{1}$ : Data tidak homogen.

Kriteria Uji : Jika nilai $\chi_{\text {hitung }}^{2} \leq \chi_{\text {tabel }}^{2}$ maka $H_{0}$ diterima, sehingga kedua data homogen.

Setelah dilakukan uji normalitas dan uji homogenitas maka akan dilanjutkan dengan uji t 2 sampel tidak berkolerasi dengan rumusan hipotesis uji pihak kanan sebagai berikut:

$$
\begin{aligned}
& H_{0}: \mu_{1} \leq \mu_{2} \\
& H_{1}: \mu_{1}>\mu_{2}
\end{aligned}
$$

Kriteria Uji :Jika $t_{\text {hitung }} \leq t_{\text {tabel }}$, maka $H_{0}$ diterima.

Ket:

$\mu_{1}$ : Kemampuan Komunikasi yang Menerapkan Model Problem Solving

$\mu_{2}$ : Kemampuan Komunikasi yang Menerapkan Model Konvensional

\section{HASIL DAN PEMBAHASAN}

Adapun hasil pretest kemampuan komunikasi matematis materi persamaan garis lurus dibawah ini: 
kelas eksperimen 1 yang meliputi mean, modus, serta nilai tengah (median) berturut-turut sebesar 72,66, 78,57 dan 78,57. Untuk kelas eksperimen 2 nilai mean, modus, dan median adalah sebesar 71,21, 71,43 dan 75. Sedangkan untuk kelas kontrol nilai mean, modus, dan median sebesar 66,63, 71,43 dan 71,43 . Ukuran variansi kelompok yang meliputi jangkauan atau rentang deviasi untuk kelas eksperimen 1 sebesar 42,86, pada kelas eksperimen 2 sebesar 35,71, sedangkan pada kelas kontrol sebesar 32,14. Simpangan baku kelas eksperimen 1 sebesar 11,24, kelas eksperimen 2 yaitu 7,94, sedangkan kelass kontrol yaitu 10,04. Berikut ini data hasil posttest materi persamaan garis lurus dapat dilihat pada tabel berikut ini:

Tabel 2. Data Hasil Posttest Kemampuan Komunikasi Matematis

\begin{tabular}{|c|c|c|c|c|c|c|c|}
\hline \multirow{2}{*}{ Kelompok } & \multirow[b]{2}{*}{$X_{\max }$} & \multirow[b]{2}{*}{$X_{\min }$} & \multicolumn{3}{|c|}{ Ukuran Tendensi Sentral } & \multicolumn{2}{|c|}{$\begin{array}{l}\text { Ukuran variansi } \\
\text { kelompok }\end{array}$} \\
\hline & & & $\overline{\bar{X}}$ & $M_{o}$ & $M_{e}$ & $\mathbf{J}$ & $\mathbf{S}$ \\
\hline Eksperimen 1 & 100,00 & 67,86 & 84,49 & 85,71 & 89,29 & 32,14 & 9,62 \\
\hline Eksperimen 2 & 100,00 & 50,00 & 80,80 & 92,86 & 85,71 & 50,00 & 11,25 \\
\hline Konvensional & 92,86 & 57,14 & 74,44 & 71,43 & 75,00 & 35,72 & 8,39 \\
\hline
\end{tabular}

Berlandaskan tabel 2 terlihat bahwa nilai posttest dengan nilai tertinggi pada kelas eksperimen 1 dan 2 sebesar 100, namun nilai terendah untuk kelas eksperimen 2 yaitu sebesar 50,00 dan kelas kontrol adalah 57,14. Pada kelas eksperimen 1 nilai mean, modus dan mediannya berturut-turut sebesar 84,49, 85,71, dan 89,29. Pada kelas eksperimen 2 nilai mean, modus, dan mediannya sebesar 80,80, 92,86, dan 85,71 . Sedangkan untuk kelas kontrol nilai mean, modus dan mediannya sebesar 74,44, 71,43, 75 .

Sedangkan untuk ukuran variansi pada kelas eksperimen 1 sebesar 32,14, kelas eksperimen 2 sebesar 50,00, dan kelas kontrol sebesar 35,72. Serta simpangan baku pada kelas eksperimen 1 sebesar 9,62, kelas eksperimen 2 sebesar 11,25 dan kelas kontrol sebesar 8,39 . Hasil perhitungan dari variansi satu jalan sel tak sama pretest dapat dilihat pada tabel berikut ini.

Tabel 3. Rangkuman Anava Satu jalan Pretest

\begin{tabular}{|c|c|c|c|c|c|}
\hline Sumber Keragaman & JK & dk & RK & F $_{\text {hitung }}$ & $\mathrm{F}_{\text {tabel }}$ \\
\hline Metode Pembelajaran & 653,404 & 2 & 326,702 & 3,572 & 3,09 \\
\hline Galat & 8231,636 & 90 & 91,463 & & \\
\hline Total & 8885,04 & 92 & & & \\
\hline
\end{tabular}

Berlandaskan tabel di atas terlihat bahwa hasil dari perhitungan uji analisis yang telah dilakukan sehingga diperoleh $\mathrm{F}_{\text {hitung }}=3,572$, sedangkan pada $\mathrm{F}_{\text {tabel }}=3,09$ (lihat $\mathrm{F}$ tabel untuk $\mathrm{Dk}=2$ dan N-1=90). Kemudian $\mathrm{F}_{\text {hitung }}$ tersebut dibandingkan dengan $\mathrm{F}_{\text {tabel }}$. Dikarenakan 3,572>3,09 maka $\mathrm{H}_{0}$ ditolak, artinya ketiga perlakuan tersebut memberikan pengaruh yang berbeda-beda terhadap peningkatan kemampuan komunikasi peserta didik. Adapun hasil perhitungan dari anava satu jalan posttest bisa dilihat pada tabel dibawah ini ini: 
Tabel 4. Rangkuman Anava Satu Jalan Posttest

\begin{tabular}{|c|c|c|c|c|c|}
\hline Sumber Keragaman & JK & dk & RK & $\mathrm{F}_{\text {hitung }}$ & $\mathrm{F}_{\text {tabel }}$ \\
\hline Metode Pembelajaran & 1706,016 & 2 & 853,008 & 9,52 & 3,09 \\
\hline Galat & 8066,72 & 90 & 89,628 & & \\
\hline Total & 9772,54 & 92 & & & \\
\hline
\end{tabular}

Berlandaskan tabel di atas dapat dilihat bahwa dari perhitungan pengujian analisis yang telah dilakukan diperoleh $\quad \mathrm{F}_{\text {hitung }}=9,52$, sedangkan untuk $\mathrm{F}_{\text {tabel }}=3,09$ (lihat $\mathrm{F}$ tabel untuk $\mathrm{Dk}=2$ dan $\mathrm{N}-1=90$ ). Kemudian $\mathrm{F}_{\text {hitung }}$ tersebut dibandingkan dengan $\mathrm{F}_{\text {tabel }}$. Karena 9,52 > 3,09 maka $\mathrm{H}_{0}$ ditolak, artinya ketiga perlakuan memberikan pengaruh yang tidak sama terhadap kemampuan komunikasi matematis peserta didik. Untuk melihat manakah perlakuan yang secara signifikan memberikan pengaruh yang berbeda terhadap komunikasi matematis, maka dilakukan uji komparasi ganda (uji lanjut pasca anava).

Berdasarkan dari hasil uji hipotesis dengan menggunakan anava satu jalan, disimpulkan bahwa terdapat perbedaan peningkatan terhadap kemampuan komunikasi matematis peserta didik dengan pembelajaran Problem Solving Modifikasi, pembelajaran Problem Solving dan pembelajaran konvensional. Untuk mengetahui yang manakah perlakuan yang lebih baik, peneliti melakukan uji komparansi ganda dengan dengan menggunakan uji scheffe' pada masingmasing kelompok sampel.

Hal ini diduga peserta didik dengan pembelajaran Problem Solving Modifikasi lebih cepat dalam meningkatkan komunikasi matematis, karena Problem Solving Modifikasi memudahkan peserta didik untuk memahami materi karena peserta didik diajarkan untuk memecahkan masalah, membuat masalah dan solusinya serta membuat rangkuman materi. Hal ini diduga berpengaruh dalam menyebabkan pembelajaran Problem Solving Modifikasi menghasilkan kemampuan komunikasi yang lebih baik daripada pembelajaran Problem Solving.

Peserta didik dengan metode Problem Solving Modifikasi lebih cepat dalam meningkatkan komunikasi matematis, karena Problem Solving Modifikasi memudahkan peserta didik untuk memahami materi karena peserta didik diajarkan untuk memecahkan masalah, membuat masalah dan solusinya serta membuat rangkuman materi. Sedangkan pembelajaran konvensional hanya mengandalkan ceramah yang diberikan oleh guru sehingga siswa kurang aktif dalam proses belajar mengajar.

Hal tersebut diduga berpengaruh pada pembelajaran yang menggunakan metode Problem Solving Modifikasi lebih baik daripada pembelajaran konvensional dalam meningkatkan komunikasi matematis. Berdasarkan hasil perhitungan dengan metode scheffe', diperoleh hasil bahwa terdapat perbedaan antara pembelajaran yang menggunakan metode problem solving dengan pembelajaran konvensional terhadap kemampuan komunikasi matematis peserta didik. Dilihat dari nilai rata-rata kelas diketahui bahwa pembelajaran dengan menggunakan metode problem solving lebih baik dari pembelajaran konvensional. 


\begin{abstract}
Hal ini mungkin disebabkan karena pembelajaran dengan menggunakan metode Problem Solving mempunyai kelebihan yaitu dapat memberikan kesempatan pada peserta didik untuk memecahkan masalah baik individu maupun secara berkelompok, melatih peserta didik untuk mempresentasikan dan mendengarkan semua hasil permasalahan yang telah dipecahkan secara berkelompok, serta pengetahuan peserta didik dapat bertambah luas. Peserta didik juga sangat berantusias serta dapat bertanggung jawab dengan kelompoknya Hal ini diduga berpengaruh dalam menyebabkan model pembelajaran Problem Solving menghasilkan komunikasi yang lebih baik daripada model pembelajaran konvensional.
\end{abstract}

Penelitian yang dilakukan sebelumnya oleh Nurlaila, Suparmi dan Sunarno (2013) menemukan bahwa pembelajaran dengan menggunakan metode Problem Solving terbukti berpengaruh untuk meningkatkan kemampuan kreatifitas serta kemampuan berfikir Kritis Peserta didik. Penelitian yang dilakukan oleh Suhendri (2015) menyimpulkan bahwa pembelajaran dengan menggunakan metode Problem Solving terbukti lebih efektif terhadap hasil belajar untuk meningkatkan kemandirian belajar peserta didik.

\section{KESIMPULAN}

Dari hasil penelitian diperoleh kesimpulan bahwa terdapat perbedaan peningkatan kemampuan komunikasi matematis peserta didik pembelajaran problem solving, metode pembelajaran problem solving modifikasi dan metode pembelajaran konvensional. Sehingga dapat disimpulkan bahwa metode pembelajaran problem solving modifikasi dan metode pembelajaran problem solving lebih baik dibandingkan dengan metode pembelajaran konvensional, dan pembelajaran problem solving modifikasi lebih baik dibandingkan pembelajaran problem solving. Setelah menarik kesimpulan diatas, maka peneliti dapat memberikan saran sebagai berikut: 1) Pembelajaran Problem solving modifikasi ini dapat menghasilkan kemampuan komunikasi matematis lebih baik lagi. 2) Peneliti berharap dapat mengembangkan penelitian ini untuk serta model pembelajaran lainnya sehingga bisa menambah wawasan serta dapat meningkatkan kualitas pendidik adar lebih baik.

\section{DAFTAR PUSTAKA}

Agustiana, N., Supriadi, N., \& Komarudin, K. (2019). Meningkatkan kemampuan penalaran matematis dengan penerapan pendekatan bridging analogy ditinjau dari selfefficacy. Inovasi Pembangunan: Jurnal Kelitbangan, 7(1), 61-61.

Ainiyah, N. (2013). Pembentukan karakter melalui pendidikan agama islam. Al-Ulum, 13(1), 25-38.

Anisah, A., Zulkardi, Z., \& Darmawijoyo, D. (2013). Pengembangan soal matematika model PISA pada konten quantity untuk mengukur kemampuan penalaran matematis siswa sekolah menengah pertama. Jurnal Pendidikan Matematika Sriwijaya, 5(1), 121613.

Anwar, N. T. (2018). Peran kemampuan literasi matematis pada 
pembelajaran matematika abad-21. In Prisma, Prosiding Seminar Nasional Matematika (Vol. 1, pp. 364-370).

Aprilia, D. (2014). Studi komparatif model CIRC dan MMP terhadap kemampuan berpikir kreatif peserta didik. Unnes Journal of Mathematics Education, 3(3).

Astuti, A., \& Leonard, L. (2015). Peran kemampuan komunikasi matematika terhadap prestasi belajar matematika siswa. Formatif: Jurnal Ilmiah Pendidikan MIPA, 2(2).

Darmawan, M. (2015). Peningkatan kemandirian peserta didik melalui strategi pembelajaran problem solving pada kompetensi perawatan dan perbaikan PC di kelas X TKJ SMK Negeri 3 Yogyakarta. Jurnal Eksplorasi Karya Sistem Informasi dan Sains, 6(2).

Emda, A. (2011). Pemanfaatan media dalam pembelajaran biologi di sekolah. JURNAL ILMIAH DIDAKTIKA: Media Ilmiah Pendidikan dan Pengajaran, 12(1), 149-162.

Farida, F. (2015). Mengembangkan kemampuan pemahaman konsep peserta didik melalui pembelajaran berbasis VCD. Al-Jabar: Jurnal Pendidikan Matematika,6(1), 2532.

Hariawan, H., Kamaluddin, K., \& Wahyono, U. (2014). Pengaruh model pembelajaran creative problem solving terhadap kemampuan memecahkan masalah fisika pada siswa kelas XI SMA Negeri 4 Palu. JPFT (Jurnal Pendidikan Fisika Tadulako Online), 1(2), 48-54.

Hartoyo, A. (2012). Eksplorasi etnomatematika pada budaya masyarakat dayak perbatasan indonesia-malaysia kabupaten sanggau kalbar. Jurnal Penelitian Pendidikan, 13(1), 14-23.
Hidayati, F., Isnani, I., \& Susongko, P. (2017). Pengaruh persepsi peserta didik pada pembelajaran matematika terhadap prestasi belajar matematika di sekolah menengah pertama. JPMP (Jurnal Pendidikan MIPA Pancasakti), 1(1).

Ikhsan, M. (2019). Pengaruh kecemasan matematis terhadap hasil belajar matematika. De Fermat: Jurnal Pendidikan Matematika, 2(1), 1-6.

Karim, A. (2011). Penerapan metode penemuan terbimbing dalam pembelajaran matematika untuk meningkatkan pemahaman konsep dan kemampuan berpikir kritis siswa sekolah dasar. Jurnal pendidikan, 1(1), 21-32.

Manullang, M. (2016). Pengaruh penguasaan numerik dan penguasaan verbal terhadap prestasi belajar matematika. Jurnal Ilmu Pendidikan, 10(2).

Nadi, C. Y., ES, W. A., \& Saputro, S. (2016). Pengaruh metode problem solving secara algoritmik dan heuristik terhadap prestasi belajar ditinjau darikemampuan metakognisi siswa pada materi kelarutan dan hasil kali kelarutan kelas XI MIA di SMA N 5 surakarta. Jurnal Pendidikan Kimia (JPK), 5(1), 125-133.

Nurlaila, N., Suparmi, S., \& Sunarno, W. (2013). Pembelajaran fisika dengan PBL menggunakan problem solving dan problem posing ditinjau dari kreativitas dan keterampilan berpikir kritis siswa. INKUIRI: Jurnal Pendidikan IPA, 2(02).

Permana, Y., \& Sumarmo, U. (2007). Mengembangkan kemampuan penalaran dan koneksi matematik siswa SMA melalui pembelajaran berbasis masalah. educationist, 1(2), 116-123.

Purwanto, S. (2016). Pengembangan web site matematika sekolah untuk meningkatkan hasil belajar mahasiswa, siswa sekolah 
menengah dan sekolah dasar. In Prosiding Konferensi Nasional Penelitian Matematika dan Pembelajarannya (KNPMP) I

Rachmayani, D. (2014). Penerapan Pembelajaran Reciprocal Teaching untuk meningkatkan kemampuan komunikasi matematis dan kemandirian belajar matematika siswa. JUDIKA (Jurnal Pendidikan Unsika), 2(1).

Ratnasari, I. W. (2017). Hubungan minat belajar terhadap prestasi belajar matematika. Psikoborneo, 5(2), 400-405.

Rindyana, B. S. B., \& Chandra, T. D. (2012). Analisis kesalahan siswa dalam menyelesaikan soal cerita matematika materi sistem persamaan linear dua variabel berdasarkan analisis Newman (Studi
Kasus MAN Malang 2 Batu). Artikel Ilmiah Universitas Negeri Malang, 1(2).

Rohman, A. A., Yuniarti, S., \& Permatasari, B. I. (2018). Pengaruh metakognisi dan kreativitas terhadap kemampuan pemecahan masalah matematis siswa kelas X IPS SMA Negeri 4 balikpapan tahun ajaran 2017/2018. De Fermat : Jurnal Pendidikan Matematika, 1(2), 2530.

https://doi.org/https://doi.org/10.362 77/defermat.v1i2.23

Suhendri, H. (2015). Pengaruh metode pembelajaran problem solving terhadap hasil belajar matematika ditinjau dari kemandirian belajar. Formatif: Jurnal Ilmiah Pendidikan MIPA, 3(2). 